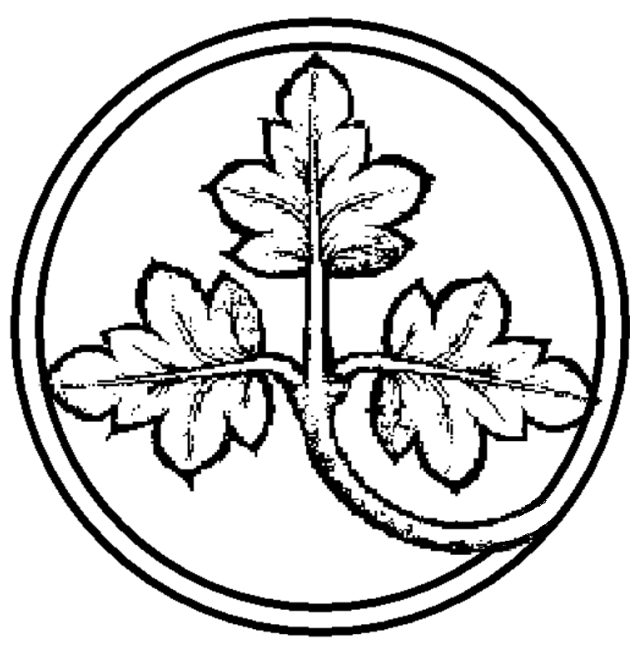

\author{
Preprints of the \\ Max Planck Institute \\ for Research on Collective Goods \\ Bonn \\ 2005/5
}

The Role of Liquidity and Implicit Guarantees in the German Twin Crisis of 1931

Isabel Schnabel 


\section{The Role of Liquidity and Implicit Guarantees in the German Twin Crisis of 1931}

Isabel Schnabel

March 2005 


\title{
The Role of Liquidity and Implicit Guarantees in the German Twin Crisis of 1931
}

\author{
Isabel Schnabel* \\ Max Planck Institute for Research on Collective Goods, Bonn
}

\begin{abstract}
Using monthly balance-sheet data of all major German credit banks, we analyze deposit withdrawals and bank failures in the German banking and currency crisis of 1931. We find that deposit withdrawals were driven by the run on the currency, but were also related to banks' liquidity positions; that branch banks were no more stable than unit banks; and that large banks were privileged, being bailed out and receiving preferential access to the discount window. These findings underline the importance of liquidity and implicit guarantees in twin crises, while they question the benefits of branching in such crises. (JEL: G21, E5, N24, C34; Keywords: Twin crises, liquidity, implicit guarantees, "too big to fail".)
\end{abstract}

*Max Planck Institute for Research on Collective Goods, Kurt-Schumacher-Str. 10, 53113 Bonn, Germany. E-mail: schnabel@coll.mpg.de. Phone: +49-228-91416 65. Fax: +49-22891416 21. I would like to thank Reinhold Schnabel for very helpful discussions in the early stages of this project. Moreover, I thank Jochen Bigus, Christoph Buchheim, Mark Carlson, Martin Hellwig, HansJoachim Voth, David Wheelock and the participants of the Annual Meeting of the Cliometric Society in Raleigh, the European Economic Association in Stockholm, the Economic History Association in Nashville, the Verein für Socialpolitik in Zürich, the Banking Workshop in Münster as well as seminar participants at Pompeu Fabra in Barcelona, Humboldt University in Berlin, the University of Mannheim, Middelbury College and Harvard University for useful comments and suggestions. 


\section{Introduction}

The high incidence of financial crises in the past decades has inspired a large amount of literature on the determinants of financial instabilities. One can distinguish two distinct strands within that literature: The first one is concerned with the microeconomics of banking, such as risk allocation and moral hazard, and its implications for banking stability and regulation. The other strand deals with the macroeconomic aspects of financial crises, such as the first- and second-generation models of currency crises. The severe crises of the 1990s shifted the attention to "twin crises," involving the simultaneous collapse of the currency and the banking sector. These crises revealed the necessity of combining the two strands of literature in order to understand the interactions between the micro- and the macroeconomic factors in such crises.

This led to the emergence of the third-generation models of crises, which are dominated by two ideas: The first is the role of moral hazard and implicit public guarantees in twin crises, the other, the effects of depreciations of the domestic currency on banks' balance sheets. However, this literature is predominantly theoretical, whereas the empirics of twin crises are still poorly understood. The most well-known empirical paper on twin crises is the one by Kaminsky and Reinhart (1999). By analyzing the timing of banking and currency crises across a large sample of countries, the authors establish a number of stylized facts about twin crises. Their main results are that banking and currency crises became more closely linked after the financial liberalization in the 1980s, and that banking crises typically preceded currency crises. However, due to its high level of aggregation, the analysis cannot tell us anything about the "microeconomics of twin crises."

This paper tries to fill this gap by analyzing one particular crisis on the basis of individual bank data, namely the German twin crisis of 1931. This crisis seems to be well-suited for the study of the issues involved. First, the episode shares many features with the more recent crises: The banks had accumulated large amounts of short-term foreign currency debt at low interest rates. When capital flows reversed abruptly, the banks faced serious liquidity problems due to heavy deposit withdrawals, culminating in the collapse of the banks and the fixed peg. However, the largest banks were bailed out by the government. This raises the questions whether these banks were considered to be "too big to fail," and what role implicit guarantees played in the German crisis. $^{1}$

\footnotetext{
${ }^{1}$ Implicit government guarantees have figured prominently in the explanations of the more recent crises.
} 
Second, there exists monthly balance-sheet data of all major German credit banks. ${ }^{2}$ This disaggregated data allows us to trace the relationship between the microeconomic behavior of banks and the macroeconomic developments. By exploiting the heterogeneity across banks, we can distinguish between competing explanations of twin crises. Most importantly, we ask whether the run on German banks was caused by the run on the currency, or whether it was driven by depositors who had doubts about their banks' soundness.

Third, the crisis took place in an environment where market discipline was not hampered by an explicit deposit insurance scheme, or by the existence of an international institution such as the International Monetary Fund. This fact allows us to isolate the effects of domestic implicit guarantees to the largest German banks by comparing their performance with that of smaller banks. To our knowledge, our paper is the first to explicitly test for the existence of implicit government guarantees in twin crises at a disaggregated level. Given the strong emphasis on such guarantees in the third-generation crisis models, such evidence is particularly important.

Finally, the German crisis allows us to examine the benefits of branch networks in twin crises because the banks in the sample differ regarding the extent of their branch networks. It is a widely maintained hypothesis that branch banks are more stable than non-branch banks. The question is whether this claim is still true at times of severe macroeconomic shocks, when there is not much to be gained from regional diversification.

Our analysis yields the following results: First, the run on the German currency translated into a run on banks; banks exhibited particularly high deposit withdrawals at times of currency turmoil, especially if their shares of foreign deposits were high. However, deposit withdrawals were also related to the banks' strength, in particular to their liquidity ratios. This stresses the role of liquidity in twin crises. Taken together, these results indicate that the banking and the currency crisis were superimposed upon, and presumably reinforced, each other. This is consistent with Kaminsky and Reinhart's (1999) evidence of a vicious spiral between the two phenomena. Second, there is no evidence that branch banks were more stable than unit banks. Branch banks exhibited neither lower deposit withdrawals, nor a lower probability of failure. This suggests that branch networks are of little help in

See, e.g., Krugman (1998) and Corsetti et al. (1999).

${ }^{2}$ This data has hardly been used. Most analyses of the German crisis are based on aggregate data. The only other microeconometric study is by Petri (1998), who conducts a survival analysis of German banks. 
the presence of large macroeconomic shocks as are common in twin crises. ${ }^{3}$ Third, there is strong evidence that large banks had a higher probability of survival and somewhat weaker evidence that this translated into lower deposit withdrawals, controlling for the riskiness of banks' portfolios. We also find that large banks were more likely to be bailed out and that they received preferential access to the Reichsbank's discount window. This supports the view that large banks were considered to be "too big to fail," and underlines the importance of implicit guarantees in twin crises. ${ }^{4}$

Our results can be compared with the small, but growing microeconometric literature on the more recent twin crises, most notably on Argentina. ${ }^{5}$ Schumacher (2000) finds that, similar to our findings, in the Tequila crisis of 1994/95 - which was not really a twin crisis because the fixed peg did not collapse in the end - the run on banks was related to individual banks' weaknesses, and was not just a consequence of the run on the currency. However, liquidity factors appear to have played a much smaller role than in the German crisis. In contrast, Burdisso and D'Amato (2002) find for the 2001/02 crisis that deposit withdrawals were not linked at all to individual banks' characteristics, but were rather driven by macroeconomic shocks alone. However, this result may be driven by the fact that most bank characteristics vary at a lower frequency than the macroeconomic variables used in the regressions. None of these papers deals with the role of implicit government guarantees or branching. However, Schumacher (2000) finds that the explicit deposit insurance scheme introduced in 1995 in Argentina deterred depositors from withdrawals.

The paper is organized as follows: In section 2, we briefly describe the history of the German crisis. Then we formulate the hypotheses that form the basis of our empirical analysis. In section 4, we describe the dataset and its major properties. Sections 5 and 6 contain the two econometric parts: the first one analyzes deposit flows, the second standby activities. Section 7 concludes. The appendix contains a number of supplementary tables.

\footnotetext{
${ }^{3}$ Carlson (2004) finds similar evidence for U.S. banks during the Great Depression. In fact, branch banks are found to be less likely to survive and to survive for shorter periods of time. This contradicts the conventional wisdom.

${ }^{4}$ Kryzanowski and Roberts (1993) document a similar phenomenon at Canadian banks in the same time period. For the 1980s, Boyd and Gertler (1994) present evidence for a "too-big-to-fail" problem at U.S. commercial banks with strikingly similar results to ours.

${ }^{5}$ Berlemann et al. (2002) analyze the Bulgarian twin crisis, but they do not use individual bank data.
} 


\section{History of the German crisis ${ }^{6}$}

After Germany's return to the gold standard in 1923, the German banking sector experienced a rapid expansion during the second half of the 1920s. Due to the scarcity of domestic savings, this expansion was financed largely by foreign debt. In 1929, 18 percent of all deposits in the banking sector were foreign, most of it short-term deposits. In 1928, foreign lending to Germany started to decrease, and Germany experienced gold outflows from 1930 on. German GDP growth slowed down substantially in 1928 and became negative in 1929, which was the beginning of a deep recession with rapidly increasing unemployment, a dramatically shrinking money supply, and tumbling prices.

Even before the crisis of 1931, there were several episodes of financial instability. Two crises were related to political events, the first to the imminent breakdown of reparations negotiations in the spring of 1929, the second to the governmental crisis in July 1930 and particularly to the Reichstag elections in September 1930. The Reichsbank's gold cover and bank deposits decreased substantially in these crises (figure 1), but there were no significant number of bank failures. Another crisis was related to the breakdown of the second largest German insurance company, FAVAG, in the fall of 1929. A number of banks failed in that crisis, but there were hardly any macroeconomic repercussions.

The crisis of 1931 again took place in an environment of political disturbances, culminating in a memorandum of the Brüning government on June 6 stating that Germany was no longer able or willing to bear the burden of reparations. At the same time, bad news from the banking sector drew attention to the vulnerabilities of the banks. The publication of huge losses at the largest Austrian bank, "Österreichische Creditanstalt," on May 11 raised fears of similar weaknesses in Germany due to the similarity between the Austrian and the German banking systems. Then, about the time of the reparations memorandum, first rumors about problems at the second largest German bank, Danatbank, started to spread. A few days later, the information about disastrous losses at Nordwolle, a textile company, began to circulate. This gave rise to further speculations about Nordwolle's major creditors, Danatbank and Dresdner Bank, whose exposure to Nordwolle was substantial.

\footnotetext{
${ }^{6}$ This section follows Schnabel (2004a). That paper also contains an extensive bibliography of the crisis.
} 


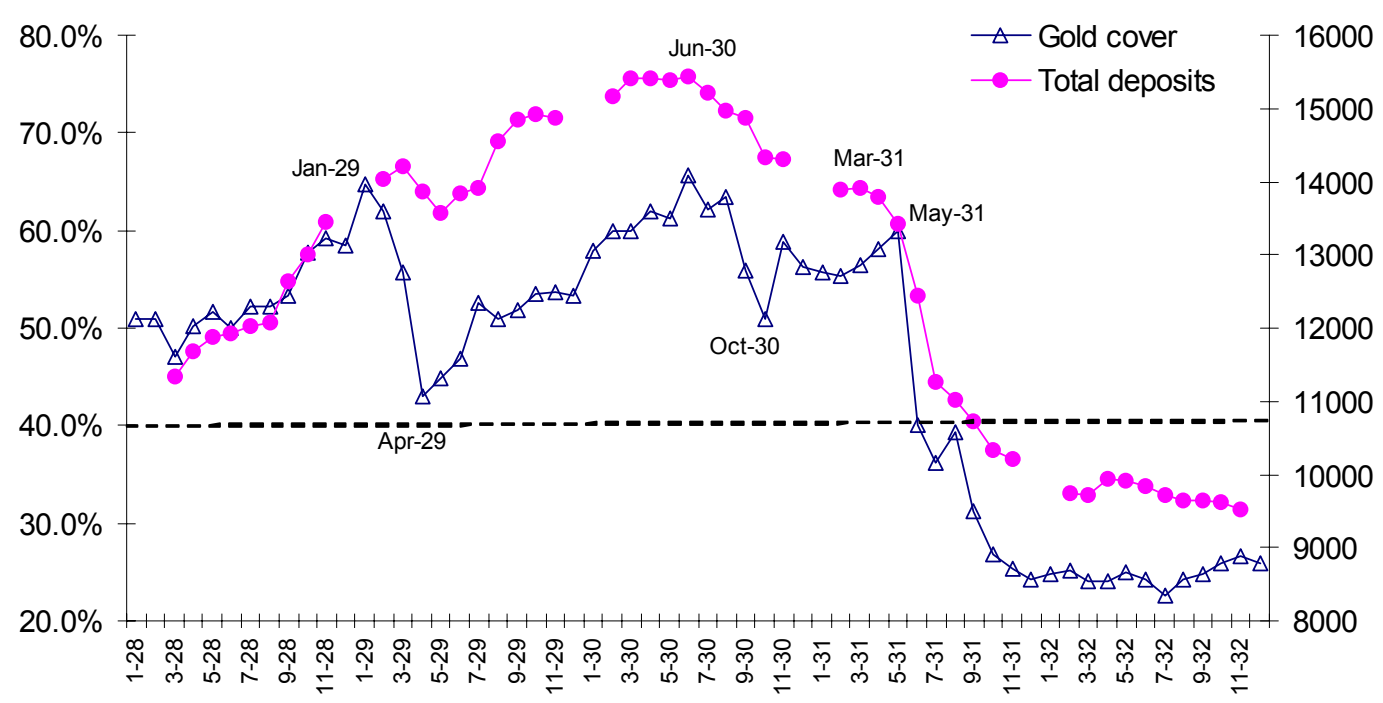

Figure 1: The Reichsbank's gold cover and the evolution of total deposits. Notes: The gold cover is defined as the share of Reichsbank reserves in the Reichsbank note circulation (in percent, left scale). Total deposits are deposits at monthly reporting credit banks, including acceptances (in million Reichsmark, right scale). Gaps are due to missing data. The dashed line denotes the 40 percent mandatory gold cover under the gold standard.

Severe pressure on the currency and heavy deposit withdrawals accompanied these events (figure 1), and the Reichsbank discounted large numbers of bills to keep the banking system liquid. Due to continuing reserves losses, the Reichsbank felt impelled to tighten its liquidity provision on July 10. This triggered the breakdown of Danatbank. A general banking panic erupted as soon as the breakdown of Danatbank became public on July 13. The banking system was temporarily suspended by the declaration of bank holidays. The banking panic was accompanied by huge reserve losses at the Reichsbank, and the gold cover quickly fell below the forty-percent minimum. On July 15, the Reichsbank suspended convertibility of the Reichsmark into gold and imposed capital controls, which set an end to the gold standard in Germany. The payments system operated on a restricted scale until the beginning of August. Negotiations with foreign creditors resulted in a standstill agreement on part of the international debt. Bank failures played only a minor role in the German crisis, as all of the largest banks were saved by public capital injections. The crisis gave rise to national banking supervision and to tightened banking regulation.

In summary, the German crisis displayed the same boom-and-bust cycle as the more recent crises. The build-up of high levels of short-term foreign debt in the economy, and 
especially in the banking sector, was followed by a sudden capital reversal, which impaired both the banking sector and the currency. After the crisis there were some major bail-outs by the public authorities, suggesting the potential role of implicit government guarantees in the crisis. Note, however, that there was no devaluation after the crisis, so the currency crisis did not affect banks through balance-sheet effects.

\section{Hypotheses}

To structure the discussion, the analysis will be based on four hypotheses. All hypotheses are complementary, rather than mutually exclusive. The currency-crisis hypothesis states that the run on the currency translated into deposit withdrawals from banks. Under this hypothesis, investors withdrew their bank deposits because they had doubts about Germany's ability and willingness to service its foreign debt and about the stability of the currency. Then we would expect deposit withdrawals to be particularly high at times of currency disturbances. Moreover, withdrawals should be related to a bank's share of foreign deposits because foreign depositors (mostly foreign banks in our case) are likely to react more strongly than domestic depositors, who also need their deposits for transaction purposes. ${ }^{7}$

According to the banking-crisis hypothesis, depositors withdrew their funds from banks that they considered to be weak. Then deposit withdrawals should be related to banks' (perceived) solvency or liquidity positions. ${ }^{8}$ It should be stressed that these two hypotheses are not mutually exclusive. It is well possible that the causalities in twin crises go in both directions, and that the two types of crises are superimposed upon, or even reinforce, each other. For example, the withdrawals accompanying a run on the currency weaken banks' liquidity positions, which may induce further withdrawals from illiquid banks. Also, the run on the currency may raise fears that certain banks become insolvent in case of devaluation,

\footnotetext{
${ }^{7}$ However, the same observation would also be consistent with the view that depositors considered banks with high shares of foreign deposits to be particularly vulnerable to devaluation. Therefore, it does not allow us to distinguish between the currency-crisis and the banking-crisis hypothesis.

${ }^{8}$ In the economic history literature, there is an active debate on whether the German crisis was a banking or a currency crisis. See Hardach (1976), Balderston (1994), and Ferguson and Temin (2003) for the currency view, and Born (1967) and James (1984) for the banking view. For a reconciliation of these two views, see Schnabel (2004a) and the following discussion by Ferguson and Temin (2004) and Schnabel (2004b).
} 
triggering withdrawals from banks with high shares of foreign-currency deposits. Conversely, deposits withdrawn from weak banks may be transferred abroad, putting pressure on the currency.

The branching hypothesis claims that banks maintaining branch networks were more stable than unit banks. ${ }^{9}$ Branch banks should be more diversified on both the asset and the liabilities sides and should therefore be less vulnerable to local or regional shocks. Under the branching hypothesis, banks maintaining branch networks are expected to display lower deposit withdrawals and to have lower failure probabilities than unit banks. In order to separate the effects of branching and size, it is important to simultaneously include a measure of size, such as total assets. Note that the rejection of the branching hypothesis does not imply that branch networks never offer any protection to banks. Instead, it would point towards the lower benefits of branch networks in crises that are driven by macroeconomic shocks, as is the case in twin crises.

Finally, the too-big-to-fail hypothesis states that large banks were considered to be too important to be allowed to fail. This hypothesis implies that large banks should be less likely to fail, and more likely to be bailed out, than small banks (at a given portfolio risk). If depositors anticipate the bail-outs of large banks, these banks should also display lower deposit withdrawals, holding constant the riskiness of the banks' portfolios. Moreover, the central bank may privilege large banks in the provision of liquidity. In a twin crisis with sudden capital reversals, liquidity becomes an important determinant of banks' survival. Therefore, the evidence on liquidity provision is particularly instructive. ${ }^{10}$

\footnotetext{
${ }^{9}$ The hypothesis that branch banking has a stabilizing effect was first stated by Friedman and Schwartz (1963, pp. 352). It was based on the experience from the Great Depression when the United States, a country with severe branching restrictions, suffered much more from bank failures than Canada, where interstate branching was permitted.

${ }^{10}$ We do not test directly for higher risk-taking at the large banks because many aspects of risk-taking are difficult to measure with balance-sheet data. Schnabel (2004a) presents some quantitative and anecdotal evidence of excessive risk-taking at the largest banks in the German crisis.
} 


\section{Data}

\subsection{Description of data sources ${ }^{11}$}

Monthly balance sheets of German banks have been published in Deutscher Reichs- und Preußischer Staatsanzeiger since March 1928. Only publicly traded banks were required to publish interim balance sheets. Many other banks published their balances voluntarily. Our sample stretches from March 1928 till the end of 1932, shortly before the take-over of power by Hitler. To avoid interference with the annual balances, no monthly balances were provided for the months of December and January. Thus, our sample contains a total of 49 months with balance-sheet data. The high frequency of balances is a particularly attractive property of the dataset, as it permits a detailed analysis of deposit flows over time. Monthly balances were "raw" balances, which means that earnings and losses were booked only once a year. This raises measurement problems with respect to capital as well as to all items that are subject to depreciation, such as loans and securities. In contrast, the distortions on items like deposits or liquid assets should be negligible.

The sample contains 110 credit banks. The sample is highly unbalanced because only 50 of these banks published balance sheets in all months. With respect to total assets, the sample comprises about one third of the German banking sector. However, the banks in our sample were holding about 80 percent of the banking sector's aggregate foreign debt. ${ }^{12}$ Therefore, these banks are well-suited for the study of the dynamics of the twin crisis.

The balance-sheet data is supplemented by data from various sources. One variable of major importance is banks' foreign debt, which cannot be inferred from monthly balance sheets. However, monthly reporting banks had to report their levels of foreign debt confidentially to the Reichsbank on a quarterly basis. This data was never published, but it partly exists in the Reichsbank's archival material in the Bundesarchiv in Berlin. While the available information is not sufficient to construct time series for all the banks in our

\footnotetext{
${ }^{11}$ A detailed list of the descriptive statistics and sources of the variables used in the analysis can be found in table $\mathrm{A} 2$ in the appendix.

${ }^{12}$ The sample excludes public banks, cooperative banks, private bankers, and smaller credit banks. Of these, only the private bankers were holding significant amounts of foreign debt. However, the information on them is very fragmentary, even at the aggregate level.
} 
sample, we were able to construct a measure of the level of foreign debt as of June 30, 1930.13 If the relative importance of withdrawals of domestic and foreign deposits was comparable across banks, this measure should capture the cross-sectional differences in the vulnerability of banks to short-term capital reversals reasonably well. ${ }^{14}$

Information on banks' failures and mergers as well as on public standby activities were retrieved from the periodical Die Bank, which contains a detailed chronology of events in the German banking sector. Data on the banks' branch networks is from Saling's Börsenpapiere (1930). In addition to the data on individual banks, we collected a large number of national and regional variables. For banks with national branch networks, we inserted the figures for the German Reich when using regional variables.

\subsection{Descriptive analysis}

\subsubsection{Bank characteristics}

Most of the 110 credit banks in our sample were universal banks. Only a small subset of 16 banks $(15 \%)$ were specialized, mostly sector-specific banks. The banks in our sample were spread all over the German Reich. With respect to total assets, Berlin clearly stood out as all six of the so-called "great banks" were based in Berlin. More than two thirds of all the banks had at least one branch outside of their home base, and one fourth maintained at least ten branches. Only eight banks maintained a nationwide branch network.

The German credit banks relied heavily on foreign funds for their financing, with 29 percent of their total deposits being foreign. However, foreign debt was distributed very unevenly across banks, with particularly high shares of foreign deposits at the great branch banks. At 37 percent of the credit banks, foreign deposits constituted more than ten percent

\footnotetext{
${ }^{13}$ The data on foreign debt used in this study can be found in the following files from the Bundesarchiv Berlin, Reichsbank R2501: 6479, 6482, 6484, 6491-2, 6559, 6634, 6709, 6746, 7712. The construction of the foreign-debt variable is described in the appendix.

${ }^{14}$ Our measure seems preferable to the level of medium-term deposits, which has been used as a proxy for foreign debt (see Balderston, 1994, and Petri, 1998). That variable leads on average to a strong overestimation of the share of foreign deposits: According to our measure, the average share of foreign deposits was 16 percent on June, 30, 1930; the alternative measure gives an average of 39 percent with the measurement error ranging from -7 to +91 percentage points.
} 
of total deposits, and at 15 percent of the banks the share was above thirty percent.

19 banks in our sample (17\%) failed between 1928 and 1932. In addition, twelve banks (11\%) received public support, three of which still failed. It is interesting to compare the four different bank groups, the failing banks, with or without public support, and the surviving banks, with or without public support. Table 1 summarizes the major findings. For comparison, it includes an extra column on the great branch banks.

\begin{tabular}{|l|c|c|c|c||c|}
\cline { 2 - 6 } \multicolumn{1}{c|}{} & \multicolumn{4}{c||}{ All credit banks } & $\begin{array}{c}\text { Great } \\
\text { branch banks }\end{array}$ \\
\cline { 2 - 6 } \multicolumn{1}{c|}{} & Failing banks & \multicolumn{2}{c|}{ Surviving banks } & Surviving \\
\hline Public support & no & yes & no & yes & yes \\
\hline \hline Number of banks & 16 & 3 & 64 & 9 & 4 \\
\hline Total assets, median (million RM) & 7 & 11 & 8 & 352 & 1,815 \\
Total assets, maximum (million RM) & 19 & 38 & 1,039 & 3,784 & 3,784 \\
\hline \# branches, median & 2 & 3 & 2 & 83 & 206 \\
\# branches, maximum & 17 & 19 & 154 & 301 & 301 \\
\hline Share of foreign deposits, median & $9 \%$ & $9 \%$ & $9 \%$ & $38 \%$ & $41 \%$ \\
Share of foreign deposits, maximum & $16 \%$ & $11 \%$ & $81 \%$ & $48 \%$ & $45 \%$ \\
\hline Cash liquidity, median & $1.4 \%$ & $1.2 \%$ & $2.5 \%$ & $2.0 \%$ & $1.9 \%$ \\
\hline Equity ratio, median & $21 \%$ & $14 \%$ & $19 \%$ & $16 \%$ & $7 \%$ \\
\hline
\end{tabular}

Table 1: Characteristics of different bank groups. Notes: The numbers refer to the month before failure for failing banks, and to November 1931 for surviving banks. The number of banks in this table is below 110 because it does not include surviving banks for which there is no valid data for November 1931. Note that the great branch banks are also contained in the column "All credit banks."

Table 1 suggests the following preliminary observations: First, outright bank failures played a minor role in the German crisis. The failing credit banks, supported or not supported, were very small banks with few branches and low levels of foreign debt. In contrast, the banks that survived with the help of public support were much more important in terms of total assets, foreign debt, and the number of branches. Six of the ten largest German banks, among them all the great branch banks, belonged to this group. In fact, the sum of total assets of all failing banks was well below the median of total assets of the banks that received public support and survived. Hence, the real problem in the German crisis of 1931 were not the banks that actually failed, but the ones that survived only with the help of the public authorities. Finally, the surviving banks that received support had lower liquidity and equity ratios than the banks that survived without such support. Particularly low equity ratios were found at the great branch banks. 


\subsubsection{Evolution of deposits}

Table 2 conveys a first impression of the heterogeneity of deposit withdrawals across different bank groups. ${ }^{15}$ It shows the mean deposit changes for the period between June 1930 and November 1931, during which the largest part of withdrawals took place.

\begin{tabular}{|lcc|}
\hline & $\begin{array}{c}\text { Number } \\
\text { of banks }\end{array}$ & $\begin{array}{c}\text { June 1930 to } \\
\text { November 1931 }\end{array}$ \\
\hline Monthly reporting credit banks & 76 & $-21.6 \%$ \\
\hline 10 largest credit banks & 10 & $-30.0 \%$ \\
Banks other than 10 largest credit banks & 66 & $-20.3 \%$ \\
\hline 1 branch & 23 & $-21.8 \%$ \\
\# branches $>1$, not nationally & 48 & $-20.8 \%$ \\
Nationwide branch network & 5 & $-27.9 \%$ \\
\hline Share of foreign deposits $<10 \%$ & 50 & $-18.9 \%$ \\
$10 \% \leq$ share of foreign deposits $<30 \%$ & 13 & $-21.9 \%$ \\
Share of foreign deposits $\geq 30 \%$ & 13 & $-31.5 \%$ \\
\hline
\end{tabular}

Table 2: Percentage change in deposits between June 1930 and November 1931 for different bank groups. Notes: The numbers show the means of the respective bank groups. The table contains all banks for which deposit data was available at both dates.

Deposits at monthly reporting credit banks decreased by 21.6 percent on average in the considered time period. The highest withdrawals of deposits were found at the ten largest credit banks, which lost 30.0 percent of their deposits, while the remaining banks lost only 20.3 percent on average. Hence, the raw data provides no evidence that large banks were perceived as being particularly safe. Interestingly, the relationship between withdrawals and branching is not monotonic. The highest withdrawals were found at the banks maintaining nationwide branch networks, while the lowest withdrawals were found at banks maintaining regional branch networks. This cannot easily be reconciled with the view that branch banks were more stable than non-branch banks. As expected, banks with higher shares of foreign deposits show higher deposit withdrawals. As the following regression analysis will show, not all results that come out of the descriptive analysis are preserved once we appropriately control for all relevant factors.

\footnotetext{
${ }^{15}$ The variable used in the following analysis is "total deposits." It is the sum of the following balancesheet items: Foreign acceptance loans ("Seitens der Kundschaft bei Dritten benutzte Kredite"), domestic interbank deposits ("Deutsche Banken, Bankfirmen, Sparkassen und sonstige deutsche Kreditinstitute"), other deposits, including foreign interbank deposits ("Sonstige Kreditoren"), and domestic acceptance loans ("Akzepte").
} 


\subsubsection{Liquidity provision to banks}

In the presence of sudden capital reversals, the liquidity of banks becomes a crucial determinant of survival. Hence, in a twin crisis the provision of liquidity by the central bank is one of the major instruments that can be used to privilege banks. Therefore, an analysis of the liquidity provision to banks provides a way of testing for implicit guarantees to the largest banks.

The discounting of bills was the major instrument of the Reichsbank for providing liquidity to the banking sector. Open market operations were still uncommon at that time, and the amount of lombard loans was small compared to the discounting of bills. The extent of discounting can be assessed by analyzing the evolution of the endorsement liabilities of banks. In the analysis, we are going to use the off-balance-sheet item "other endorsement liabilities," which comprises all the bills of exchange that a bank has passed on, apart from bank acceptances and promissory notes.

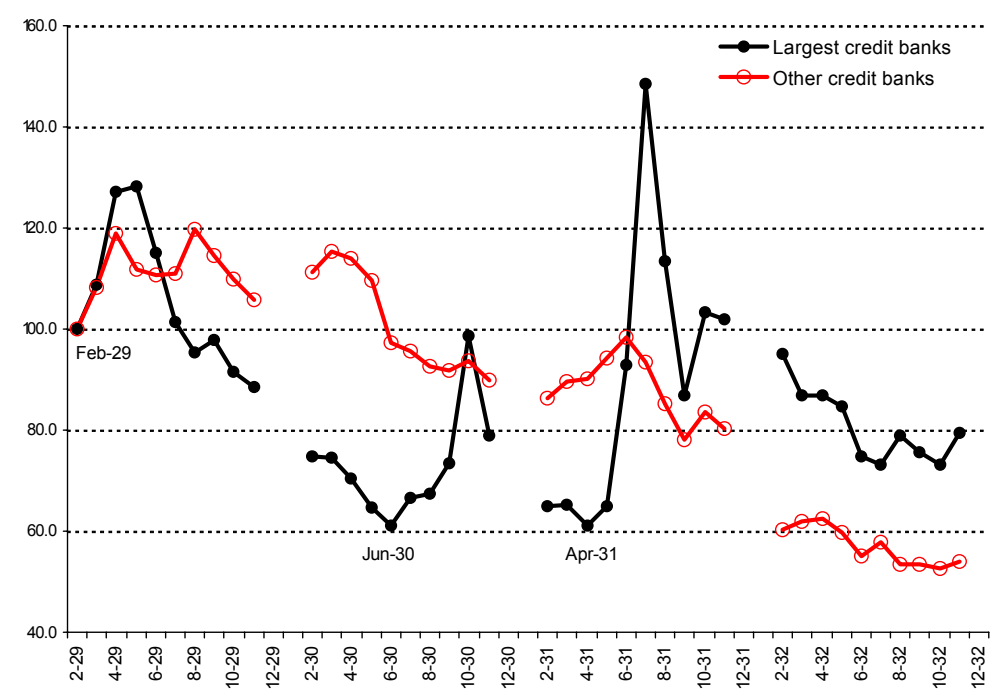

Figure 2: Other endorsement liabilities at the largest monthly reporting credit banks and at other monthly reporting credit banks, February $1929=100$. Notes: The largest credit banks are the great Berlin banks and the four largest provincial banks plus all the banks that were merged to any of these in the period under consideration. The group "other credit banks" refers to a constant sample of 59 banks. Gaps in the graphs are due to missing data.

A comparison of the evolution of endorsement liabilities across different bank groups shows that at times of currency turmoil and banking problems - here, namely in the spring 
of 1929, the fall of 1930, and the summer of 1931 - there were sharp increases in endorsement liabilities at the largest credit banks (see figure 2). At the remaining credit banks, endorsement liabilities increased only mildly in these months, compared to the largest banks. The question to be answered in the following econometric analysis is whether the particularly large increase in discount loans at the largest banks was due to their preferential access to the Reichsbank's discount window, as would be predicted by the "too-big-to-fail" hypothesis.

\section{Econometric analysis of deposit flows}

\subsection{Deposit flows and bank failures}

Most existing microeconometric studies on banking crises model the incidence of bank failures in the context of a hazard model, whereas there are very few papers analyzing deposit flows. Due to the minor importance of bank failures in the German crisis, an analysis including deposit flows is clearly preferable to one based on bank failures alone. In addition, deposits react promptly to macroeconomic shocks and to bank-specific information, whereas failures typically occur with a lag. However, an analysis of deposit flows may suffer from a selection problem because the banks with the highest deposit withdrawals are most likely to leave the sample. Therefore, we model deposit flows in a Heckman (1979) selection model, as will be described in the following subsection. This has a nice side effect: namely, it allows us to simultaneously model the evolution of deposits and the occurrence of bank failures. ${ }^{16}$

\subsection{Estimation procedure}

Our sample is subject to a problem of non-random sample attrition: Banks join and leave the sample, and the selection into the sample may depend on the changes in deposits. The problematic cases are bank failures and distress mergers (i. e. a bank close to failure is taken over by another bank), which are likely to be related to deposit changes. If a bank leaves the sample for other reasons, this is assumed to be independent of deposit changes. Banks resulting from mergers are treated like new banks. A list of all failures, distress mergers, and public standby activities can be found in table A1 in the appendix.

\footnotetext{
${ }^{16}$ Schumacher (2000) and Burdisso and Amato (2002) ignore this selection problem.
} 
To correct for non-random sample attrition, we estimate a Heckman (1979) selection model. The evolution of deposits is described by the following equation:

$$
\hat{d}_{i t}^{*}=x_{i t} \beta+\varepsilon_{i t},
$$

where $\hat{d}_{i t}^{*}$ is the (latent) monthly change in the deposits of bank $i$ at time $t$, and $x_{i t}$ is a vector of bank-specific, region-specific, macroeconomic and other explanatory variables. Selection into the sample is determined by the following equation:

$$
p_{i t}^{*}=z_{i t} \alpha+\nu_{i t}
$$

where $p_{i t}^{*}$ is a latent variable that determines the observability of $\hat{d}_{i t}^{*}$ : If $p_{i t}^{*} \geq 0$, the bank remains in the sample (indicated by a binary variable, which is equal to one in this case) and we observe the true value of $\hat{d}_{i t}^{*}$. If $p_{i t}^{*}<0$, the bank leaves the sample (in which case the binary variable is equal to zero), and we do not observe latent deposit growth. In both cases, we observe the control variables $x$ and $z$. We assume that the two disturbance terms are jointly normally distributed with a correlation coefficient $\rho$.

In principle, the parameters in this model are identified through functional form assumptions. However, identification is generally believed to be more credible if one includes at least one variable in the selection equation that is not contained in the equation of interest. In our case, there is a natural means of identification. Monthly balance sheets were published with a delay of almost a full month. For instance, the balance sheet referring to March 1928 was published at the end of April 1928. Hence, depositors could react to this balance sheet no earlier than May 1928. In contrast, the probability of failure clearly would depend on the most recent balance-sheet figures. Therefore, we exclude the most recent lags of the balance-sheet variables from the deposit equation. ${ }^{17}$

\subsection{Estimation results}

Table 3 presents the results for our main regression equation. We use robust standard errors throughout. The definitions of all variables can be found in the appendix. The upper part of the panel displays the deposit equation, the lower part the selection equation.

\footnotetext{
${ }^{17}$ In the checks for robustness, we also estimated the model using panel methods (fixed effects or ArellanoBond estimators). However, these methods estimate the model in first differences, implying that all factors that are time-invariant, such as branching and foreign debt, are not identified.
} 
The dependent variable in the main equation is the logarithm of the growth factor of total deposits at German credit banks. ${ }^{18}$ In the selection equation, the dependent variable is a dummy variable, which is equal to one if the bank's balance sheet is observed, and zero in the month when the bank leaves the sample. We also report standardized coefficients. These give the number of standard deviations that the dependent variable changes when one increases the independent variable by one standard deviation; for dummy variables, the standardized coefficient refers to a change in the independent variable from zero to one (in those cases, the standardized coefficients are given in italics). Note that these coefficients are "exact" only in linear regressions. The standardized coefficients allow us to compare the economic (and not just the statistical) significance of different coefficients.

The results of the deposit equation strongly support the currency-crisis hypothesis. The variable "gold cover," which measures the strength of the currency, enters with a positive sign and is highly significant, implying that a strong currency was accompanied by high deposit growth (or low withdrawals). We also find that banks with higher shares of foreign deposits ("foreign share") showed significantly higher deposit withdrawals than other banks, which is in line with the idea that foreign depositors reacted more strongly to currency problems than domestic depositors did. The results also support the banking-crisis hypothesis. Most importantly, there is a positive and significant relationship between a bank's "cash liquidity" and its deposit growth. The standardized coefficient is relatively large, implying that the effect is also economically important. ${ }^{19}$ Moreover, lagged deposit growth positively affects current deposit growth. One possible interpretation is that depositors consider banks to be fragile that suffered from high deposit withdrawals in the past.

With respect to solvency, the matter is less clear-cut. The "equity ratio" has the expected sign, but it is insignificant; this may be due to the fact that book capital is a poor measure of a bank's solvency. The impact of the stock market crash is measured by the variable

\footnotetext{
${ }^{18}$ The use of growth factors is preferable to the use of levels since the levels of variables as deposits are typically non-stationary. The logarithms are used to remove the skewness from the dependent variable and to transform the growth factor into a variable that is defined on the entire real line.

${ }^{19}$ The coefficient of 0.0078 can be interpreted as follows: If the liquidity of one bank is 10 percent higher than that of another bank, the growth factor is increased by 0.078 percent on a monthly basis. This corresponds approximately to an annual increase in deposit growth by 1 percentage point, assuming that the growth factor is close to 1 . This is still reinforced through the positive autocorrelation in deposit growth.
} 
"stocks," which is the growth of a general stock index, interacted with the bank's share of stocks in total assets; this variable, too, is insignificant.

\begin{tabular}{|c|c|c|c|c|c|}
\hline $\begin{array}{l}\text { Dependent } \\
\text { variable }\end{array}$ & Independent variables & Coefficient & $\begin{array}{c}\text { Robust } \\
\text { standard } \\
\text { errors }\end{array}$ & p-value & $\begin{array}{c}\text { Standardized } \\
\text { coefficient }\end{array}$ \\
\hline Deposit growth & $\begin{array}{l}\text { Deposit growth }(-2) \\
\text { Deposit growth }(-3) \\
\text { Cash liquidity }(-2) \\
\text { Equity ratio }(-2) \\
\text { Branching } \\
\text { Foreign share } \\
\text { Public } \\
\text { Total assets }(-2) \\
\text { Bank stocks }(-1) \\
\text { Insolvencies }(-1) \\
\text { Regional employment }(-1) \\
\text { Stocks }(-1) \\
\text { Gold cover }(-1) \\
\text { Constant }\end{array}$ & $\begin{array}{c}0.0415 \\
0.0752 \\
0.0078 \\
0.0040 \\
0.0016 \\
-0.0070 \\
0.0015 \\
0.0024 \\
0.2808 \\
-0.0344 \\
-0.0089 \\
-0.9821 \\
0.0137 \\
0.3065\end{array}$ & $\begin{array}{l}0.0322 \\
0.0270 \\
0.0020 \\
0.0031 \\
0.0033 \\
0.0024 \\
0.0039 \\
0.0008 \\
0.0754 \\
0.0059 \\
0.0080 \\
0.8032 \\
0.0041 \\
0.0671\end{array}$ & $\begin{array}{l}0.197 \\
0.005 \\
0.000 \\
0.189 \\
0.619 \\
0.004 \\
0.697 \\
0.002 \\
0.000 \\
0.000 \\
0.268 \\
0.221 \\
0.001 \\
0.000\end{array}$ & $\begin{array}{c}0.0493 \\
0.0830 \\
0.0923 \\
0.0365 \\
0.0236 \\
-0.0658 \\
0.0220 \\
0.0650 \\
0.0810 \\
-0.1180 \\
-0.0209 \\
-0.0676 \\
0.0683 \\
--\end{array}$ \\
\hline Select & $\begin{array}{l}\text { Deposit growth (-1) } \\
\text { Deposit growth }(-2) \\
\text { Deposit growth (-3) } \\
\text { Cash liquidity }(-1) \\
\text { Cash liquidity }(-2) \\
\text { Equity ratio }(-1) \\
\text { Equity ratio (-2) } \\
\text { Branching } \\
\text { Foreign share } \\
\text { Public } \\
\text { Total assets }(-2) \\
\text { Bank stocks }(-1) \\
\text { Insolvencies }(-1) \\
\text { Regional employment }(-1) \\
\text { Stocks (-1) } \\
\text { Gold cover }(-1) \\
\text { Constant } \\
\text { Rho }\end{array}$ & $\begin{array}{c}1.9609 \\
2.0851 \\
-0.7226 \\
0.3168 \\
-0.1294 \\
0.6507 \\
-0.2944 \\
0.0632 \\
0.1285 \\
0.0441 \\
0.2212 \\
1.4533 \\
-0.5442 \\
0.0664 \\
-0.8503 \\
0.1773 \\
7.5672 \\
0.0415\end{array}$ & $\begin{array}{l}0.5251 \\
0.6180 \\
0.7610 \\
0.1244 \\
0.1339 \\
0.2555 \\
0.2371 \\
0.1660 \\
0.1010 \\
0.3804 \\
0.0796 \\
4.5268 \\
0.3573 \\
0.6473 \\
6.6144 \\
0.3505 \\
4.3975 \\
0.0627\end{array}$ & $\begin{array}{l}\mathbf{0 . 0 0 0} \\
\mathbf{0 . 0 0 1} \\
0.342 \\
\mathbf{0 . 0 1 1} \\
0.334 \\
\mathbf{0 . 0 1 1} \\
0.214 \\
0.703 \\
0.203 \\
0.908 \\
\mathbf{0 . 0 0 5} \\
0.748 \\
0.128 \\
0.918 \\
0.898 \\
0.613 \\
\mathbf{0 . 0 8 5} \\
0.509\end{array}$ & $\begin{array}{c}2.3158 \\
2.4358 \\
-0.7787 \\
3.6877 \\
-1.5047 \\
5.7817 \\
-2.6136 \\
0.8961 \\
1.1773 \\
0.6257 \\
5.8494 \\
0.4096 \\
-1.8266 \\
0.1526 \\
-0.0571 \\
0.8617 \\
--\end{array}$ \\
\hline $\begin{array}{l}\text { \# Obs (total) } \\
\text { \# Failures } \\
\text { Wald test } \mathrm{Chi}^{2}(14): \\
\mathrm{p} \text {-value }\end{array}$ & $\begin{array}{r}3800 \\
19 \\
144.58 \\
\mathbf{0 . 0 0 0 0}\end{array}$ & & & & \\
\hline
\end{tabular}

Table 3: Results from selection model for growth in total deposits.

Another measure of a bank's perceived solvency is its stock price. Since individual stock prices are not available for all the banks in our sample, we included the growth of an aggregate price index of "bank stocks," and it proved to be strongly significant and economically 
important. However, this variable is uninformative with respect to the effect of individual bank solvency on deposit withdrawals. The insignificance of the bank-specific solvency variables may be due to measurement problems. However, it is also possible that depositors reacted much more strongly to liquidity than to solvency indicators, because information on liquidity was more readily available and because liquidity becomes the crucial determinant of survival in twin crises with sudden capital reversals.

The branch structure does not have a significant impact on deposit flows; the "branching" dummy, indicating that a bank has more than one branch, is insignificant. "Regional employment," which is to measure regional shocks, does not enter significantly in the equation either. In contrast, the lagged number of national bankruptcies ("insolvencies") is highly significant. This indicates that deposit flows were related to national rather than regional shocks, explaining why a branch network offered little protection. Note that the inclusion of monthly time dummies leaves all of our main results virtually unchanged. Hence, our macroeconomic variables appear to capture the macroeconomic evolution very well.

The variable "total assets" is positive and significant, implying that large banks experienced lower deposit withdrawals than small banks, given the riskiness of their portfolios. This is consistent with a "too-big-to-fail" interpretation: Large banks' creditors may have trusted more in the safety of their deposits, because they anticipated that their banks had a higher probability of being supported in a crisis. The result is all the more striking if we compare it to the descriptive results in section 4.2: There we have seen that large banks experienced particularly high deposit withdrawals. If we accept the "too-big-to-fail" interpretation, this means that large banks would have suffered even higher withdrawals in the absence of an implicit guarantee.

We now turn to the interpretation of the selection equation. $\rho$, which denotes the correlation coefficient of the disturbances in the two equations, and hence the conditional correlation between changes in deposits and bank survival, shows the expected sign, but it is insignificant. This indicates that selection is not an important issue in this dataset; this may be due to the low number of failures in our sample. It is still worthwhile to have a look at the determinants of bank survival. Lagged "deposit growth" has a positive and significant effect on bank survival. Hence, high withdrawals in the past increase the probability of failure. Bank survival also depends positively on a bank's strength, as measured by liquidity and equity ratios. Bank survival is unrelated to the presence of a branch network or to the share of 
foreign debt. In contrast, bank size has a highly significant positive effect on bank survival; large banks had a higher probability of survival than small banks. Again, this is consistent with large banks being "too big to fail." ${ }^{20}$ None of the macroeconomic variables enters the selection equation significantly; this suggests that the incidence of failures was related much more to bank-specific characteristics than to macroeconomic variables.

We can conclude that the results from table 3 support the currency- and the bankingcrisis hypotheses, which is consistent with the view that the currency and the banking crisis were superimposed upon, and possibly reinforced, each other. The strong relationship between banks' liquidity ratios and deposit withdrawals stresses the role of liquidity in twin crises. We can reject the branching hypothesis, since the maintenance of a branch network affects neither deposit growth nor bank survival. Finally, the significant impact of size on the deposit growth and bank survival is consistent with the "too-big-to-fail" hypothesis.

\subsection{Robustness checks}

We performed a large number of robustness checks concerning the choice of dependent variable, sample period, bank groups in the sample, the treatment of outliers, and finally the estimation method. Table A3 in the appendix summarizes the major results from these regressions. Here we only want to stress some interesting findings that came out of these additional regressions. As you can see from table A3, most of the effects shown in the basic regression in table 3 are robust to the modifications. The only result that proves not to be entirely robust is the relationship between bank size and deposit growth. In contrast, size has a very robust effect on the survival probability.

One may argue that our evidence is not sufficient to support the banking-crisis hypothesis because one should always observe higher withdrawals at weaker banks if depositors distinguish at all between stronger and weaker banks. To counter this objection, we reran the regression allowing for a structural break between crisis and non-crisis periods. If banking problems were an independent cause of the German twin crisis, we would expect the relationship between banks' liquidity and solvency and deposit withdrawals to be amplified in crisis periods. Indeed, we find that the effects of liquidity and banks' stock prices are

\footnotetext{
${ }^{20}$ In a strict sense, the "too-big-to-fail" problem refers to the ex-ante probability of failure. Therefore, a test based on ex-post probabilities is, of course, imperfect.
} 
reinforced in crisis periods, defined as months with a decrease in aggregate deposits (see table A4). This suggests that depositors reacted more strongly to information about their bank's strength in times of crisis, which underlines the importance of banking problems in explaining deposit withdrawals, especially during crisis periods. The coefficient of the share of foreign deposits also increases in size, suggesting that foreign withdrawals were also more important in crisis periods.

Moreover, one may wonder whether our results are biased due to the banks' unobserved heterogeneity. Note first that any unobserved effect in the levels of deposits would have been differenced out by the use of growth factors. To control for unobserved effects in the growth factors, we reran our regressions using panel methods (see table A5). The left panel of the table displays the results from a fixed effects regression. With weak dependence of the time series process of deposits, the inconsistency resulting from using fixed effects in the presence of lagged dependent variables is of the order $T^{-1}$ (Wooldridge 2002, p. 302), which is small given the length of our panel. However, we also present the results from an Arellano-Bond (1991) estimation (right panel). In both cases, we neglect the selection problem. We added an interaction term of the gold cover and the foreign share, because the variable "foreign share" drops out in both regressions due to the differencing of the data; this does hardly affect the remaining coefficients. The main finding is that the effect of liquidity is very robust and much stronger than in the pooled regression. The coefficients of the gold cover and the new interaction term also support the results from the pooled regression; again the results are generally stronger. However, the effect of total assets is negative and strongly significant. This result is driven by the fact that the panel methods use only the withinvariation, i.e. the variation of total assets of one bank over time. In our test, however, we are interested in the cross-sectional variation of total $\operatorname{assets}^{21}$; in fact, the fixed effects prove to be strongly positively correlated (cross-sectionally) with the initial total assets, controlling for other variables. ${ }^{22}$ This supports our result from the pooled regression. For completeness, we also present the results of regressions where total assets are not included (see table A5).

\footnotetext{
${ }^{21}$ Even a drop in total assets by 30 percent at Deutsche Bank would not change the relative size of the bank much, compared to the remaining banking sector. Especially, it would not affect the perception that Deutsche Bank is too big to fail.

${ }^{22}$ Note also that the results from the pooled regression are virtually unchanged when one uses initial total assets instead of current total assets.
} 
Regarding the impact of a bank's size on deposit withdrawals and failure probabilities, one may wonder whether this result is driven merely by the four largest banks, namely the great branch banks. Therefore, we allowed for a structural break between the great branch banks and the remaining banks. Interestingly, none of the effects hinges on the presence of the great branch banks in the sample. In particular, "total assets" remain significant for the other banks in the deposit equation. This indicates that the implicit guarantee was not believed to be limited to the great branch banks.

In addition, one may expect the relationship between bank-specific characteristics and deposit withdrawals to change after public standby activities. In order to check this, we allowed coefficients for supported banks to change after the standby activity. The most important result is that the effect of liquidity is significantly smaller for the supported banks. This suggests that the link between bank-specific characteristics and changes in deposits was weakened for supported banks, which is in line with a moral-hazard argument. In fact, the structural break is significant at a 5 percent confidence level.

We can conclude that most of the effects shown in the basic regression in table 3 are robust to the modifications. Hence, the robustness checks confirm the acceptance of both the currency- and the banking-crisis hypothesis. We can reject the branching hypothesis, as the maintenance of a branch network affects neither deposit growth nor bank survival. Finally, the relationship between asset size and deposit growth is not entirely robust. Hence, we cannot assert with confidence that larger banks exhibited lower deposit withdrawals. In contrast, size has a very robust effect on the survival probability. Thus, we can safely claim that larger banks were less likely to fail.

\section{Econometric analysis of standby activities}

\subsection{Estimation procedure and results}

The preceding analysis of deposit flows has confirmed one necessary condition for the contention that large banks were considered to be "too big to fail," namely that larger banks had a lower probability of failure than smaller banks. The results suggest that this may also have translated into lower deposit withdrawals, even though this effect is not entirely robust. While both results are consistent with the "too-big-to-fail" explanation, they could 
also indicate that large banks were better able to withstand the crisis for other reasons such as better diversification. ${ }^{23}$ Therefore, we also directly analyze public standby activities to find out whether large banks received privileged treatment in times of crisis. The descriptive analysis in section 4.2 has already shown that many large banks benefited from public support activities, and that the increase in endorsement liabilities in times of crisis was particularly strong at the larger banks. We will now examine these preliminary findings more thoroughly in an econometric analysis.

First, we check whether the probability of receiving public support was higher for larger banks than for smaller ones. Table 4 presents the results of a simple cross-sectional probit regression, where the dependent variable is a dummy variable that is equal to one if a bank received public support, such as capital injections, public guarantees, or public loans other than ordinary refinancing loans provided by the Reichsbank. The independent variables refer to April 1931, the month before the beginning of the final banking crisis. ${ }^{24}$

\begin{tabular}{|l|lcccc|}
\hline $\begin{array}{l}\text { Dependent } \\
\text { variable }\end{array}$ & $\begin{array}{l}\text { Independent } \\
\text { variables }\end{array}$ & Coefficient & $\begin{array}{c}\text { Robust } \\
\text { standard } \\
\text { errors }\end{array}$ & p-value & $\begin{array}{c}\text { Standardized } \\
\text { coefficient }\end{array}$ \\
\hline Support & & & & & \\
& & & & & \\
& First-order liquidity & -0.0743 & 0.0396 & $\mathbf{0 . 0 0 8}$ & -0.3033 \\
& Equity ratio & 0.0278 & 0.0402 & 0.474 & 0.1006 \\
& Branching & 0.1242 & 0.0472 & $\mathbf{0 . 0 9 4}$ & 0.8540 \\
& Foreign share & 0.0377 & 0.0277 & 0.188 & 0.1377 \\
& Total assets & 0.0446 & 0.0201 & $\mathbf{0 . 0 0 3}$ & 0.4795 \\
\hline \# Obs & 91 & & & & \\
Pseudo R & & & & & \\
\hline
\end{tabular}

Table 4: Results from probit regression for standby activities.

As predicted by the "too-big-to-fail" hypothesis, bank size has a significantly positive effect on the probability of receiving public support, which confirms the preliminary finding

\footnotetext{
${ }^{23}$ However, recent evidence for the United States has shown that even though large banks tend to be better diversified, this does not translate into a reduction in the banks' risk (Demsetz and Strahan 1997).

${ }^{24}$ The coefficients in the table correspond to the change in the probability of being supported for an infinitesimal change in each independent continuous variable, and to the discrete change in the probability for dummy variables. All effects are evaluated at the means of the independent variables. The standardized coefficients refer to the original coefficients.
} 
from the descriptive analysis in section 4.2. An increase in total assets by one percent leads to an increase in the support probability by 0.04 percent, which is substantial if you keep in mind that the largest bank in our sample is more than 5,000 times as big as the smallest one. Note that this equation controls for other bank-specific variables. So the larger probability of support at the larger banks was not simply due to the fact that they needed the support most (for example, due to their low liquidity ratios). The branching variable is weakly significant. In fact, branch networks can be interpreted here as measuring another aspect of size, namely geographical dispersion. Moreover, we find that banks with lower first-order liquidity ratios were more likely to be supported. In contrast, there is neither a relationship to the equity ratio, nor to the share of foreign deposits.

Second, we examine the provision of liquidity by the Reichsbank. Under the gold standard, monetary policy had to proceed subject to the constraint that the gold cover did not fall below the prescribed forty-percent level. In normal times, this constraint was not binding, but in times of crisis, the Reichsbank imposed discount restrictions, trying to limit the aggregate quantity of discount loans to a level compatible with the maintenance of the gold standard. ${ }^{25}$ Hence, there were two different policy regimes for liquidity provision, a crisis regime with credit rationing and a non-crisis regime with free liquidity provision. This will be taken into account in the econometric analysis by allowing for a structural break between crisis and non-crisis periods.

The question then is how the Reichsbank distributed the given aggregate level of discount loans among different banks in the rationing regime. The "too-big-to-fail" hypothesis asserts that large banks were given privileged access to the Reichsbank's rediscounting facilities in times of crisis, meaning that larger banks were rationed less than smaller banks due to their economic significance. This is a statement about the supply of discount loans by the Reichsbank to different banks. In general, one does not observe the supply directly. In a rationing regime, however, the level of discount loans equals the minimum of supply and demand, and changes in the levels of discount loans are determined by the supply side alone as long as the rationing constraint is binding. This can be exploited here to identify the supply-side effect.

Table 5 presents the results from a selection model for the growth in endorsement liabilities. $^{26}$ The correlation coefficient $\rho$ is again insignificant. The results for the selection

\footnotetext{
${ }^{25}$ For evidence on these discount restrictions, see Schnabel (2004a).

${ }^{26}$ The regression of endorsement liabilities suffers from the same selection problem as the regression of
} 
equation are suppressed here because they are similar to the ones in the other table. In the main equation, the dependent variable is the logarithm of the growth factor of "other endorsement liabilities." The panel on the left of table 5 displays the coefficients for noncrisis periods, while the panel on the right shows the estimates for crisis periods. A crisis regime is defined as a period with aggregate deposit withdrawals. An alternative definition based on the gold cover yields almost the same classification, as the two variables are highly correlated. Under the "too-big-to-fail" hypothesis, we expect a bank's size to have a positive effect on endorsement growth in crisis periods, but not in non-crisis periods.

\begin{tabular}{|c|c|c|c|c|c|c|c|}
\hline \begin{tabular}{|l|} 
Dependent \\
variable
\end{tabular} & Independent variables & Coefficient & $p$-value & $\begin{array}{l}\text { Standardized } \\
\text { coefficient }\end{array}$ & Coefficient & p-value & $\begin{array}{l}\text { Standardized } \\
\text { coefficient }\end{array}$ \\
\hline \multirow{16}{*}{\begin{tabular}{|l|} 
Endorsement \\
growth
\end{tabular}} & \multicolumn{4}{|c|}{ No crisis } & \multicolumn{3}{|c|}{ Crisis } \\
\hline & Total assets $(-1)$ & 0.0008 & 0.848 & 0.0042 & 0.0142 & 0.018 & 0.0776 \\
\hline & Endorsement growth (-1) & -0.0782 & 0.065 & -0.0731 & -0.1153 & 0.003 & -0.1262 \\
\hline & Endorsement growth (-2) & -0.0405 & 0.232 & -0.0360 & -0.0442 & 0.152 & -0.0515 \\
\hline & Endorsement growth (-3) & -0.0294 & 0.317 & -0.0289 & -0.0626 & 0.097 & -0.0703 \\
\hline & Deposit growth (-1) & 0.3242 & 0.001 & 0.0735 & 0.3079 & 0.002 & 0.0735 \\
\hline & Deposit growth (-2) & -0.0247 & 0.694 & -0.0062 & 0.1426 & 0.267 & 0.0319 \\
\hline & Deposit growth (-3) & -0.0694 & 0.406 & -0.0148 & 0.1413 & 0.147 & 0.0328 \\
\hline & Share of bills $(-1)$ & 0.0154 & 0.023 & 0.0437 & 0.0217 & 0.006 & 0.0677 \\
\hline & Cash liquidity $(-1)$ & -0.0105 & 0.226 & -0.0249 & -0.0258 & 0.045 & -0.0616 \\
\hline & Equity ratio (-1) & -0.0079 & 0.536 & -0.0144 & 0.0143 & 0.452 & 0.0261 \\
\hline & Foreign share & -0.0150 & 0.233 & -0.0279 & -0.0130 & 0.411 & -0.0253 \\
\hline & Branching & 0.0117 & 0.462 & 0.0342 & 0.0120 & 0.577 & 0.0349 \\
\hline & Public & 0.0133 & 0.689 & 0.0387 & -0.0496 & 0.106 & -0.1444 \\
\hline & Gold cover $(-1)$ & -0.0116 & 0.719 & -0.0085 & 0.0546 & 0.008 & 0.0617 \\
\hline & Constant & -0.1007 & 0.062 & -- & -0.0626 & 0.366 & -- \\
\hline \multirow[t]{2}{*}{ Select } & $\ldots$ & & & & & & \\
\hline & Rho & -0.010 & 0.980 & & & & \\
\hline \# Obs (total) & 3,689 & & & & & & \\
\hline \# Failures & 19 & & & & & & \\
\hline \multirow{2}{*}{$\begin{array}{l}\text { Wald test } \mathrm{Chi}^{2}(30) \text { : } \\
\mathrm{p} \text {-value }\end{array}$} & 121.42 & & & & & & \\
\hline & 0.0000 & & & & & & \\
\hline
\end{tabular}

Table 5: Results from selection model for growth in endorsement liabilities, allowing for a structural break between crisis and non-crisis periods.

deposit changes. The presence of a bank in the sample depends on how much liquidity it receives from the Reichsbank and is, therefore, not random. Hence, we apply the same estimation procedure as in table 3 in order to control for non-random sample attrition. Here, we use a number of lagged macroeconomic variables (such as insolvencies, employment, stock prices) as instruments. 
The regression results strongly support the conjecture that large banks received preferential access to the Reichsbank's rediscounting facilities in times of crisis. Endorsement growth in crisis periods is significantly related to the size of banks, given the control variables, and the standardized coefficient is large compared to the other coefficients. In contrast, size does not matter in non-crisis periods. This is exactly what would have been expected under the "too-big-to-fail" hypothesis. ${ }^{27}$

It is also instructive to examine the other coefficients in the regression even though one has to be careful with a structural interpretation. ${ }^{28}$ In both crisis and non-crisis periods, the growth in endorsement liabilities displays a negative autocorrelation, meaning that high growth rates were likely to be followed by small ones and vice versa. In times of crisis, a lower cash liquidity implied a higher growth in endorsement liabilities, reflecting the greater need for liquidity. However, the discounting of bills was only possible if the bank actually possessed bill material eligible for discount. This explains the highly significant coefficient of the share of bills in total assets. The same effect is also present in non-crisis periods.

If liquidity pressure was a driving force of endorsement growth in times of crisis, one would also expect past deposit growth and the share of foreign deposits to have significant effects on endorsement growth. However, the coefficient of deposit growth has the "wrong" sign, whereas the "foreign share" is insignificant. This suggests that the process of liquidity provision was not guided by considerations of needs alone. Finally, the growth rate of endorsement liabilities depends positively on the Reichsbank's gold cover in times of crisis. This reflects the constraints imposed upon the Reichsbank by the gold standard. The higher the gold cover, the wider the Reichsbank's scope for rediscounting activities.

We can conclude that there is strong evidence that large banks received privileged treatment, both with respect to public supporting activities, such as capital injections and public guarantees, and with respect to rediscounting. In combination with our findings on deposit

\footnotetext{
${ }^{27} \mathrm{An}$ interesting question is whether the privileged treatment was anticipated by the large banks. In our sample, the correlation between the cash liquidity ratio and total assets is negative and highly significant. This is consistent with the view that large banks reduced their liquidity holdings in the anticipation of a privileged treatment at the discount window.

${ }^{28}$ Note that the regression in table 5 is not a demand or supply curve. The effect of the price variable is not modeled here. Instead, the regression gives the allocation of discount loans across different banks.
} 
flows and bank failures, this provides strong evidence for the "too-big-to-fail" hypothesis.

\subsection{Robustness checks}

We conducted a large number of robustness checks for the regression of endorsement liabilities. The simple probit regression does not lend itself to a further robustness analysis. As before, we examined the robustness of our results regarding the choice of the dependent variable, sample period, bank groups included in the sample, the treatment of outliers, and finally the estimation method. As you can see from summary table A6, the results from table 5, especially that concerning "total assets," prove to be extremely robust, strengthening our finding that large banks were privileged, being provided with greater liquidity.

One may wonder whether it is appropriate to pool the data before and after July 1931, because the process of liquidity provision may have changed after the gold standard was abandoned, since this removed an important constraint to monetary policy. Therefore, we reran the regression allowing for another structural break after July 1931 (see table A7). In fact, the results show some notable differences from the pooled regression. First, the size of a bank is significant only in crisis periods before the bank holiday, while it turns insignificant after July 1931. This suggests that large banks were privileged primarily in times when the gold standard constraint was still binding. Second, the share of bills and the gold cover are significant for crisis and non-crisis periods before July 1931, but in both cases they turn insignificant after July 1931. This indicates that the provision of liquidity in the latter period was no longer limited by gold standard considerations, nor by the availability of bills. A Chow test shows that the structural break is, in fact, significant at the 5 percent level.

Moreover, we checked again whether the results hinged on the presence of the great branch banks in the sample. Indeed, the coefficient of "total assets" becomes insignificant when we exclude the great branch banks. Hence, the privileged treatment of the great branch banks seems to drive the result regarding the effect of bank size on discounting.

We can conclude that the results from the regression of endorsement liabilities, especially that concerning "total assets," are extremely robust to various modifications. This strongly supports the view that large banks, and especially the great branch banks, enjoyed preferential access to the Reichsbank's rediscounting facilities. 


\section{Conclusion}

This paper has studied the interaction between micro- and macroeconomic factors in twin crises by analyzing one particular episode on the basis of individual bank data, namely the German twin crisis of 1931. Our analysis has shown that this crisis should be described as both a currency and a banking crisis. Deposit withdrawals were particularly high at times of currency disturbances, and banks holding foreign debt lost more deposits than other banks. In addition, illiquid banks lost more deposits than liquid banks, especially in times of crisis, indicating that depositors withdrew their funds primarily from banks that were thought to be particularly fragile. In this respect, twin crises appear to be no different from banking crises that are not accompanied by currency crises. Moreover, the incidence of failures was related much more to bank-specific characteristics than to macroeconomic variables. Thus, both deposit growth and the incidence of failures suggest that the (macroeconomic) currency crisis was accompanied by a (microeconomic) banking crisis.

Our results suggest that the particular severity of the German twin crisis, and of twin crises in general, may be due to the mutual reinforcement of banking and currency problems. A run on the currency tends to weaken banks, and the run on banks may weaken the currency. This is consistent with Kaminsky and Reinhart's (1999) conjecture that there is a vicious spiral between the two phenomena. An evaluation of the relative importance of the banking and the currency problems is beyond the scope of this paper, and it may not even be very useful, given the mutual interdependence between the two phenomena. However, we hope to shift the view away from unidirectional explanations of twin crises to a more differentiated view, where banking and currency problems may be superimposed upon, and possibly reinforce, each other.

Furthermore, our results question the benefits of branch networks in twin crises. Branch banks exhibited neither lower deposit withdrawals in times of crisis, nor a lower probability of failure. This does not necessarily mean that branch networks in general do not offer any protection. Our preferred interpretation is that national shocks were more prevalent in the German crisis than regional shocks. In such crises, the diversification effects offered by branch networks may be negligible, as many risks are not diversifiable. In fact, in our regressions, regional indicators had no significant effect on deposit growth or on the incidence of bank failures. In this respect, the German crisis seems to have been very different from the various banking crises in the United States during the Great Depression, where regional 
shocks played an important role (see, e.g., Wicker 1996).

Carlson and Mitchener (2003) have argued that branching may enhance aggregate stability by intensifying competition and forcing weak banks to exit the system. This would actually be consistent with lower stability at the individual bank level. In contrast, our findings suggest that a banking system with large branch banks is likely to be more vulnerable to financial crises. The reason is that branch banks tend to be large banks, which may suffer from a moral-hazard problem because depositors and the public authorities consider these banks to be "too big to fail." In fact, our results lend considerable support to the "too-big-tofail" hypothesis. In the German crisis, large banks were less likely to fail, and more likely to be bailed out than smaller banks. In addition, large banks received preferential access to the Reichsbank's discount window. This strongly supports the view that the public authorities considered the large banks to be "too big to fail." There is also some, albeit weaker, evidence that depositors anticipated the bail-outs and were therefore less inclined to withdraw their deposits from larger banks. Also, cash liquidity ratios are negatively correlated with the banks' size, which may suggest that the large banks themselves anticipated a privileged treatment at the discount window. By attracting high levels of "hot" foreign debt, while holding low liquidity levels, the large banks may, in fact, have increased the vulnerability of the German economy to a twin crisis.

It is worthwhile to compare these findings with the work by Kryzanowski and Roberts (1993), who have documented a similar "too-big-to-fail" problem at Canadian banks during the Great Depression. Interestingly, the diagnoses of the underlying problems are very similar, while the problems manifested themselves in very different ways: Germany experienced a severe banking crisis, while Canada (which also suffered from a currency crisis) became the prime example of the stability of large branch banks. Our analysis suggests that one possible reason for this difference is that German banks were much more reliant on foreign debt, which aggravated the intertwinement of the banking and the currency problems.

Finally, our paper has shown that the moral hazard problem does not depend on the existence of official deposit insurance or other explicit guarantees. Implicit guarantees can be just as destabilizing. In the context of a twin crisis, such guarantees become particularly problematic if they affect the provision of liquidity because the excessive provision of liquidity to some privileged banks may itself precipitate the collapse of the currency. 


\section{Appendix}

\section{Data construction}

Foreign debt variables The variable "foreign share" used in our regression analysis is defined as the share of foreign deposits in total deposits. The variable was only calculated for June 30, 1930, as there are no continuous time series for a sufficiently large number of banks. The levels of foreign acceptance loans can be obtained from the banks' monthly balance sheets, but the levels of foreign cash loans can only be inferred from archival material. For June 1930, the Reichsbank's archival material contains detailed information on the levels of foreign debt for those banks holding large amounts of foreign debt. In addition, it contains the aggregate level of foreign deposits for all monthly reporting banks. In order to estimate the levels of foreign cash loans at individual banks, the non-attributable part of the aggregate level of cash loans was distributed evenly among the remaining credit banks, assuming that the Staatsbanken, Landesbanken, and Girozentralen (SLGs) did not hold any foreign cash loans, unless it was specified explicitly in the Reichsbank's material. ${ }^{29}$ For banks that did not publish balance sheets in June 1930, the levels of acceptance loans were updated on the basis of the aggregate evolution of acceptance loans.

\footnotetext{
${ }^{29}$ This assumption is consistent with the statement in Enquête-Ausschuß (1930, p. 80) that the bulk of banks' foreign debt was held by the German credit banks and private bankers, not the SLGs.
} 
Bank failures and official standby activities Table A1 lists those banks that we have classified as failures, distress mergers, and as banks receiving official support. It also lists the respective dates.

\begin{tabular}{|l|l|l|}
\hline Date & Bank name & Classified as ... \\
\hline Sep 28 & Berliner Bankverein & Failure \\
\hline Sep 29 & Kieler Bank & Failure \\
\hline Nov 29 & Bankverein Bischofswerda & Failure \\
\hline Dec 29 & Ostbank für Handel und Gewerbe & Distress merger \\
\hline Feb 30 & Frankfurter Bankverein & Failure \\
\hline Dec 30 & Rheinisch-Westfälische Getreide-Kredit AG & Failure \\
\hline May 31 & Hansabank Oberschlesien & Failure \\
\hline May 31 & Bankhaus Bühl und Co. & Failure \\
\hline May 31 & Rheinische Bauernbank & Standby \\
\hline Jun 31 & Gewerbebank & Distress merger \\
\hline Jul 31 & Dresdner Bank & Standby \\
\hline Jul 31 & Darmstädter und Nationalbank (Danatbank) & Standby \\
\hline Jul 31 & Allgemeine Deutsche Credit-Anstalt & Standby \\
\hline Aug 31 & Hallescher Bankenverein von Kulisch, Kaempf \& Co. & Standby \\
\hline Aug 31 & Leipziger Credit-Bank & Standby \\
\hline Sep 31 & Bank für Handel und Gewerbe & Failure \\
\hline Sep 31 & Leipziger Credit-Bank & Failure \\
\hline Sep 31 & Leipziger Immobilien-Gesellschaft Bank für Grundbesitz AG & Failure \\
\hline Oct 31 & Rheinische Bauernbank & Failure \\
\hline Oct 31 & Hollandsche Credietbank & Failure \\
\hline Nov 31 & Vorschuß- und Spar-Vereins-Bank in Lübeck & Failure \\
\hline Dec 31 & Anhalt-Dessauische Landesbank & Standby \\
\hline Dec 31 & Commerz-Bank in Lübeck & Standby \\
\hline Feb 32 & Wernigeröder Bank für Handel und Gewerbe & Failure \\
\hline Feb 32 & Dresdner Bank (merged with Danatbank) & Standby \\
\hline Feb 32 & Commerz- und Privat-Bank (merged with Barmer Bank-Verein) & Standby \\
\hline Feb 32 & Allgemeine Deutsche Credit-Anstalt & Standby \\
\hline Feb 32 & Deutsche Bank und Disconto-Gesellschaft & Standby \\
\hline Jun 32 & Städte- und Staatsbank der Oberlausitz & Failure \\
\hline Jun 32 & Anhalt-Dessauische Landesbank & Distress merger \\
\hline Jul 32 & Bernburger Bank & Failure \\
\hline Aug 32 & Westfalenbank & Standby \\
\hline Tab A : Bank fanks & Soura Dje Bank. \\
\hline
\end{tabular}

Table A1: Bank failures, distress mergers, and official standby activities. Source: Die Bank. 
Descriptive statistics The following table contains the descriptive statistics of the variables used in the regressions. If the variables enter the regressions in logarithmic forms, the given statistics refer to the variables before the logarithmic transformation. The sources are denoted as follows: 1 = Deutscher Reichs- und Preußischer Staatsanzeiger, $2=$ Saling's Börsenpapiere (1930), 3 = Bundesarchiv Berlin (Reichsbank R2501, diverse files), $4=$ Die Bank (diverse issues), $5=$ Institut für Konjunkturforschung (1936), $6=$ James (1985, pp. 358).

\begin{tabular}{|c|c|c|c|c|c|c|c|c|}
\hline Variable name & Description & $\begin{array}{c}\begin{array}{c}\text { Functional } \\
\text { form }\end{array} \\
\end{array}$ & \# Obs & Mean & Std. Dev. & Min & Max & Sources \\
\hline Deposit growth & Total deposits (including acceptances) & $\begin{array}{l}\log \text { of } \\
\text { growth } \\
\text { factor }\end{array}$ & 3781 & 0.997 & 0.071 & 0.428 & 2.190 & 1 \\
\hline Cash liquidity & $\begin{array}{l}(\text { Cash }+ \text { deposits at central bank) / } \\
\text { total deposits (including acceptances) }\end{array}$ & $\log$ & 3800 & 0.026 & 0.020 & 0.000 & 0.283 & 1 \\
\hline $\begin{array}{l}\text { First-order } \\
\text { liquidity }\end{array}$ & $\begin{array}{l}\text { (Cash }+ \text { deposits at central bank }+ \\
\text { deposits at other banks }+ \text { bills of } \\
\text { exchange) / total deposits (including } \\
\text { acceptances) }\end{array}$ & $\log$ & 3800 & 0.340 & 0.478 & 0.006 & 10.905 & 1 \\
\hline Equity ratio & (Capital + reserves) / total assets & $\log$ & 3800 & 0.214 & 0.143 & 0.048 & 0.878 & 1 \\
\hline Branching & $\begin{array}{l}\text { Dummy }=1 \text { if number of branches }> \\
1,0 \text { otherwise }\end{array}$ & & 3800 & 0.680 & 0.466 & 0 & 1 & 2 \\
\hline Foreign share & $\begin{array}{l}\text { Foreign deposits / total deposits on } \\
\text { June } 30,1930\end{array}$ & $\log$ & 3800 & 0.155 & 0.137 & 0.007 & 0.814 & 3 \\
\hline Public & $\begin{array}{l}\text { Dummy = } 1 \text { if bank is public, } 0 \\
\text { otherwise }\end{array}$ & & 3800 & 0.061 & 0.240 & 0 & 1 & 2,4 \\
\hline Total assets & Total assets in million Reichsmark & $\log$ & 3800 & 165.4 & 568.4 & 0.9 & 5726.8 & 1 \\
\hline Bank stocks & Stock index for bank shares & $\begin{array}{l}\log \text { of } \\
\text { growth } \\
\text { factor }\end{array}$ & 3800 & 0.987 & 0.020 & 0.942 & 1.033 & 5 \\
\hline Insolvencies & Number of corporate insolvencies & $\log$ & 3800 & 1247 & 291 & 727 & 1972 & 5 \\
\hline $\begin{array}{l}\text { Regional } \\
\text { employment }\end{array}$ & $\begin{array}{l}\text { Regional number of employees, } \\
\text { January } 1928=100\end{array}$ & $\log$ & 3800 & 93.7 & 14.8 & 62.0 & 140.8 & 5 \\
\hline Stocks & $\begin{array}{l}\text { General stock index [Descriptive } \\
\text { statistics refer to the stock index } \\
\text { without interaction] }\end{array}$ & \begin{tabular}{|l|} 
log of \\
growth \\
factor, \\
interacted \\
with share of \\
stocks
\end{tabular} & 3800 & 0.988 & 0.040 & 0.898 & 1.130 & 5 \\
\hline Share of stocks & $\begin{array}{l}\text { Share of security portfolio in total } \\
\text { assets }\end{array}$ & & 3800 & 0.063 & 0.098 & 0.000 & 0.874 & 1 \\
\hline Gold cover & $\begin{array}{l}\text { Reichsbank reserves / Reichsbank } \\
\text { note circulation }\end{array}$ & $\log$ & 3800 & 0.478 & 0.138 & 0.225 & 0.657 & 5,6 \\
\hline $\begin{array}{l}\text { Endorsement } \\
\text { growth }\end{array}$ & Endorsement liabilities & $\begin{array}{l}\log \text { of } \\
\text { growth } \\
\text { factor }\end{array}$ & 3670 & 1.028 & 0.408 & 0.140 & 7.000 & 1 \\
\hline Share of bills & Bills of exchange / Total assets & $\log$ & 3689 & 0.138 & 0.100 & 0.000 & 0.863 & 1 \\
\hline
\end{tabular}

Table A2: Definition of variables, descriptive statistics, and sources. 


\section{Robustness checks}

\section{Deposit flows}

\begin{tabular}{|c|c|c|}
\hline $\begin{array}{l}\text { Type of robustness } \\
\text { check }\end{array}$ & Modification & Main result \\
\hline Dependent variable & Exclude domestic acceptances & All effects are robust. \\
\hline Dependent variable & $\begin{array}{l}\text { Exclude all acceptances and } \\
\text { interbank deposits }\end{array}$ & All effects are robust. \\
\hline Independent variables & Inclusion of time dummies & All effects are robust. \\
\hline Sample period & $\begin{array}{l}\text { Use crisis periods only (= } \\
\text { periods with aggregate deposit } \\
\text { withdrawals) }\end{array}$ & $\begin{array}{l}\text { Deposit equation: Coefficients of "cash liquidity" and "bank stocks' } \\
\text { increase, "total assets," "gold cover" no longer significant. } \\
\text { Selection equation: All effects are robust. (See table A4). }\end{array}$ \\
\hline Sample period & $\begin{array}{l}\text { Consider only time until July } \\
1931\end{array}$ & All effects are robust. \\
\hline Bank groups included & $\begin{array}{l}\text { Exclude banks not active in } \\
\text { retail business (deposits }<30 \% \\
\text { of total assets) }\end{array}$ & All effects are robust. \\
\hline Bank groups included & $\begin{array}{l}\text { Allow for structural break } \\
\text { between great branch banks } \\
\text { and remaining banks }\end{array}$ & $\begin{array}{l}\text { All effects are robust for remaining banks, only significant } \\
\text { deviation: coefficient of "bank stocks" larger for great branch } \\
\text { banks, structural break is weakly significant ( } p \text {-value }=0.084 \text { ). }\end{array}$ \\
\hline Bank groups included & $\begin{array}{l}\text { Allow for structural break } \\
\text { between supported and not } \\
\text { supported banks }\end{array}$ & $\begin{array}{l}\text { Coefficient of "cash liquidity" significantly smaller for supported } \\
\text { banks, structural break is significant at } 5 \%-l e v e l .\end{array}$ \\
\hline Sensitivity to outliers & Do not exclude any outliers & $\begin{array}{l}\text { "Total assets" no longer significant in deposit equations, all other } \\
\text { effects are robust. }\end{array}$ \\
\hline Sensitivity to outliers & Exclude more outliers & All effects are robust. \\
\hline Estimation method & $\begin{array}{l}\text { OLS with robust standard } \\
\text { errors }\end{array}$ & All effects are robust. \\
\hline Estimation method & $\begin{array}{l}\text { Use of panel methods (fixed } \\
\text { effects, Arellano-Bond) }\end{array}$ & $\begin{array}{l}\text { Most effects are robust. "Total assets" show "wrong" sign. But: } \\
\text { Cross-sectional correlation between initial "total assets" and fixed } \\
\text { effects as expected. (See table A5) }\end{array}$ \\
\hline
\end{tabular}

Table A3: Summary table - Robustness checks for deposit changes. 


\begin{tabular}{|c|c|c|c|c|c|}
\hline $\begin{array}{l}\text { Dependent } \\
\text { variable }\end{array}$ & Independent variables & Coefficient & $\begin{array}{l}\text { Robust } \\
\text { standard } \\
\text { errors }\end{array}$ & $p$-value & $\begin{array}{c}\text { Standardized } \\
\text { coefficient }\end{array}$ \\
\hline $\begin{array}{l}\text { Deposit } \\
\text { growth }\end{array}$ & $\begin{array}{l}\text { Deposit growth }(-2) \\
\text { Deposit growth }(-3) \\
\text { Cash liquidity }(-2) \\
\text { Equity ratio }(-2) \\
\text { Branching } \\
\text { Foreign share } \\
\text { Public } \\
\text { Total assets }(-2) \\
\text { Bank stocks }(-1) \\
\text { Insolvencies (-1) } \\
\text { Regional employment }(-1) \\
\text { Stocks }(-1) \\
\text { Gold cover }(-1) \\
\text { Constant }\end{array}$ & $\begin{array}{l}0.0077 \\
0.0970 \\
0.0106 \\
0.0029 \\
0.0058 \\
-0.0088 \\
0.0077 \\
0.0007 \\
0.4367 \\
-0.0448 \\
0.0032 \\
-1.6741 \\
0.0007 \\
0.3208\end{array}$ & $\begin{array}{l}0.0435 \\
0.0452 \\
0.0034 \\
0.0045 \\
0.0048 \\
0.0040 \\
0.0059 \\
0.0013 \\
0.1632 \\
0.0121 \\
0.0119 \\
1.5957 \\
0.0062 \\
0.1030\end{array}$ & $\begin{array}{l}0.860 \\
\mathbf{0 . 0 3 2} \\
\mathbf{0 . 0 0 2} \\
0.518 \\
0.234 \\
\mathbf{0 . 0 2 6} \\
0.192 \\
0.598 \\
\mathbf{0 . 0 0 7} \\
\mathbf{0 . 0 0 0} \\
0.791 \\
0.294 \\
0.913 \\
\mathbf{0 . 0 0 2}\end{array}$ & $\begin{array}{c}0.0082 \\
0.1068 \\
0.1204 \\
0.0257 \\
0.0004 \\
-0.0824 \\
0.1082 \\
0.0175 \\
0.1127 \\
-0.1207 \\
0.0068 \\
-0.1122 \\
0.0037 \\
--\end{array}$ \\
\hline Select & $\begin{array}{l}\text { Deposit growth }(-1) \\
\text { Deposit growth }(-2) \\
\text { Deposit growth }(-3) \\
\text { Cash liquidity }(-1) \\
\text { Cash liquidity }(-2) \\
\text { Equity ratio }(-1) \\
\text { Equity ratio }(-2) \\
\text { Branching } \\
\text { Foreign share } \\
\text { Public } \\
\text { Total assets }(-2) \\
\text { Bank stocks }(-1) \\
\text { Insolvencies }(-1) \\
\text { Regional employment }(-1) \\
\text { Stocks (-1) } \\
\text { Gold cover }(-1) \\
\text { Constant } \\
\text { Rho }\end{array}$ & $\begin{array}{c}2.0356 \\
1.9196 \\
-1.1305 \\
0.3070 \\
-0.0941 \\
0.8323 \\
-0.4220 \\
0.1455 \\
0.1415 \\
-0.1020 \\
0.2384 \\
-1.1860 \\
-0.8229 \\
0.5304 \\
-6.0124 \\
0.0173 \\
7.4184 \\
0.0470\end{array}$ & $\begin{array}{l}0.6874 \\
0.8355 \\
0.7115 \\
0.1134 \\
0.1220 \\
0.3938 \\
0.3771 \\
0.1903 \\
0.1255 \\
0.4208 \\
0.0965 \\
8.4640 \\
0.5614 \\
0.9766 \\
17.9052 \\
0.5324 \\
5.0811 \\
\\
0.0865\end{array}$ & $\begin{array}{l}\mathbf{0 . 0 0 3} \\
\mathbf{0 . 0 2 2} \\
0.112 \\
\mathbf{0 . 0 0 7} \\
0.441 \\
\mathbf{0 . 0 3 5} \\
0.263 \\
0.445 \\
0.259 \\
0.808 \\
\mathbf{0 . 0 1 4} \\
0.889 \\
0.143 \\
0.587 \\
0.737 \\
0.974 \\
0.144 \\
0.587\end{array}$ & $\begin{array}{c}1.8858 \\
1.6872 \\
-1.0160 \\
2.8932 \\
-0.8738 \\
5.9861 \\
-3.0311 \\
1.6619 \\
1.0754 \\
-1.1655 \\
5.1211 \\
-0.2503 \\
-1.8162 \\
0.9299 \\
-0.3283 \\
0.0766 \\
--\end{array}$ \\
\hline $\begin{array}{l}\text { \# Obs (total) } \\
\text { \# Failures } \\
\text { Wald test } \\
\text { Chi' }^{2}(14): \\
\text { p-value }\end{array}$ & $\begin{array}{r}1,685 \\
13 \\
\\
65.30 \\
\mathbf{0 . 0 0 0 0}\end{array}$ & & & & \\
\hline
\end{tabular}

Table A4: Robustness check for deposit changes - Restriction of sample to crisis periods. 


\begin{tabular}{|c|c|c|c|c|c|c|c|c|c|}
\hline \multirow[b]{3}{*}{$\begin{array}{l}\text { Dependent } \\
\text { variable }\end{array}$} & \multirow[b]{3}{*}{ Independent variables } & \multicolumn{4}{|c|}{ Fixed effects regression } & \multicolumn{4}{|c|}{ Arellano-Bond regression } \\
\hline & & \multicolumn{2}{|c|}{ Incl. total assets } & \multicolumn{2}{|c|}{ Without total assets } & \multicolumn{2}{|c|}{ Incl. total assets } & \multicolumn{2}{|c|}{ Without total assets } \\
\hline & & Coefficient & p-value & Coefficient & p-value & Coefficient & p-value & Coefficient & p-value \\
\hline \multirow[t]{17}{*}{$\begin{array}{l}\text { Deposit } \\
\text { growth }\end{array}$} & & & & & & & & & \\
\hline & Deposit growth (-1) & & & & & 0.0106 & 0.528 & -0.0409 & 0.024 \\
\hline & Deposit growth (-2) & 0.0363 & 0.009 & 0.0256 & 0.064 & 0.0398 & 0.019 & -0.0301 & 0.095 \\
\hline & Deposit growth (-3) & 0.0708 & 0.000 & 0.0613 & 0.000 & -0.0182 & 0.262 & -0.0677 & 0.000 \\
\hline & Cash liquidity (-2) & 0.0147 & 0.000 & 0.0189 & 0.000 & 0.0134 & 0.001 & 0.0194 & 0.000 \\
\hline & Equity ratio $(-2)$ & -0.0120 & 0.208 & 0.0120 & 0.173 & -0.2170 & 0.000 & 0.0387 & 0.363 \\
\hline & Branching & (dropped) & & (dropped) & & (dropped) & & (dropped) & \\
\hline & Foreign share & (dropped) & & (dropped) & & (dropped) & & (dropped) & \\
\hline & Public & (dropped) & & (dropped) & & (dropped) & & (dropped) & \\
\hline & Total assets $(-2)$ & -0.0567 & 0.000 & & & -0.5205 & 0.000 & & \\
\hline & Bank stocks (-1) & 0.2394 & 0.000 & 0.2665 & 0.000 & -0.0607 & 0.316 & 0.0887 & 0.179 \\
\hline & Insolvencies (-1) & -0.0251 & 0.000 & -0.0329 & 0.000 & -0.0052 & 0.450 & -0.0390 & 0.000 \\
\hline & Regional employment (-1) & 0.0028 & 0.826 & -0.0049 & 0.705 & 0.1310 & 0.000 & 0.0049 & 0.880 \\
\hline & Stocks $(-1)$ & -0.8215 & 0.001 & -0.9036 & 0.001 & 0.3194 & 0.275 & 0.1614 & 0.618 \\
\hline & Gold cover (-1) & 0.0150 & 0.014 & 0.0091 & 0.134 & 0.0619 & 0.000 & -0.0100 & 0.551 \\
\hline & $\begin{array}{l}\text { Gold cover }(-1){ }^{*} \text { Foreign } \\
\text { share }\end{array}$ & 0.0695 & 0.002 & 0.0522 & 0.022 & 0.1097 & 0.028 & 0.0548 & 0.555 \\
\hline & Constant & 0.3775 & 0.000 & 0.3603 & 0.000 & 0.0003 & 0.000 & -0.0007 & 0.014 \\
\hline \# Obs (total) & & 3,781 & & 3,781 & & 3,666 & & 3,666 & \\
\hline
\end{tabular}

Table A5: Robustness check for deposit changes - Fixed effects regression and Arellano-Bond estimation.

\section{Endorsement liabilities}

\begin{tabular}{|l|l|l|}
\hline $\begin{array}{l}\text { Type of robustness } \\
\text { check }\end{array}$ & Modification & Main result \\
\hline Dependent variable & $\begin{array}{l}\text { Include bank acceptances and } \\
\text { promissory notes }\end{array}$ & All effects are robust. \\
\hline Sample period & $\begin{array}{l}\text { Allow for another structural break } \\
\text { after July 1931 }\end{array}$ & $\begin{array}{l}\text { "Total assets", "share of bills", and "gold cover" are } \\
\text { insignificant after July 1931. Structural break is significant at } \\
\text { the 5 percent level. (See table A6). }\end{array}$ \\
\hline Bank groups included & $\begin{array}{l}\text { Exclude banks not active in retail } \\
\text { business (deposits < 30\% of total } \\
\text { assets) }\end{array}$ & All effects are robust. \\
\hline Bank groups included & $\begin{array}{l}\text { Allow for structural break between } \\
\text { great branch banks and remaining } \\
\text { banks }\end{array}$ & $\begin{array}{l}\text { Coefficient of "total assets" is insignificant for banks other } \\
\text { than the great branch banks. }\end{array}$ \\
\hline Sensitivity to outliers & $\begin{array}{l}\text { Do not exclude any outliers or } \\
\text { exclude more outliers }\end{array}$ & All effects are robust. \\
\hline Estimation method & OLS with robust standard errors & All effects are robust. \\
\hline
\end{tabular}

Table A6: Summary table - Robustness checks for endorsement liabilities. 


\begin{tabular}{|c|c|c|c|c|c|c|c|}
\hline $\begin{array}{l}\text { Dependent } \\
\text { variable }\end{array}$ & Independent variables & Coefficient & p-value & $\begin{array}{c}\text { Standardized } \\
\text { coefficient }\end{array}$ & Coefficient & p-value & $\begin{array}{c}\text { Standardized } \\
\text { coefficient }\end{array}$ \\
\hline \multirow{32}{*}{$\begin{array}{l}\text { Endorsement } \\
\text { growth }\end{array}$} & \multicolumn{4}{|c|}{ No crisis, until July 1931} & \multicolumn{3}{|c|}{ Crisis, until July 1931} \\
\hline & Total assets $(-1)$ & 0.0004 & 0.930 & 0.003 & 0.0201 & 0.013 & 0.121 \\
\hline & Endorsement growth $(-1)$ & -0.0666 & 0.136 & -0.076 & -0.1339 & 0.010 & -0.130 \\
\hline & Endorsement growth (-2) & -0.0379 & 0.312 & -0.042 & -0.1183 & 0.035 & -0.112 \\
\hline & Endorsement growth $(-3)$ & -0.0483 & 0.153 & -0.059 & -0.0775 & 0.187 & -0.075 \\
\hline & Deposit growth (-1) & 0.3961 & 0.002 & 0.109 & 0.3001 & 0.044 & 0.076 \\
\hline & Deposit growth (-2) & 0.0102 & 0.906 & 0.003 & -0.1692 & 0.349 & -0.033 \\
\hline & Deposit growth (-3) & -0.0570 & 0.582 & -0.015 & 0.0316 & 0.724 & 0.007 \\
\hline & Share of bills $(-1)$ & 0.0156 & 0.021 & 0.057 & 0.0267 & 0.011 & 0.086 \\
\hline & Cash liquidity $(-1)$ & -0.0126 & 0.141 & -0.040 & -0.0079 & 0.579 & -0.021 \\
\hline & Equity ratio $(-1)$ & -0.0129 & 0.326 & -0.031 & 0.0027 & 0.910 & 0.005 \\
\hline & Branching & 0.0154 & 0.336 & 0.059 & 0.0060 & 0.817 & 0.019 \\
\hline & Foreign share & -0.0206 & 0.104 & -0.050 & 0.0216 & 0.245 & 0.045 \\
\hline & Public & 0.0056 & 0.877 & 0.022 & -0.0271 & 0.451 & -0.087 \\
\hline & Gold cover $(-1)$ & 0.1348 & 0.029 & 0.049 & 0.1213 & 0.072 & 0.059 \\
\hline & Constant & -0.0442 & 0.518 & -- & 0.0994 & 0.242 & -- \\
\hline & \multicolumn{4}{|c|}{ No crisis, after July 1931} & \multicolumn{3}{|c|}{ Crisis, after July 1931} \\
\hline & Total assets $(-1)$ & 0.0079 & 0.589 & 0.037 & 0.0106 & 0.261 & 0.053 \\
\hline & Endorsement growth $(-1)$ & -0.1094 & 0.354 & -0.139 & -0.1196 & 0.020 & -0.142 \\
\hline & Endorsement growth (-2) & -0.0613 & 0.448 & -0.066 & -0.0181 & 0.640 & -0.024 \\
\hline & Endorsement growth $(-3)$ & 0.0731 & 0.301 & 0.089 & -0.0537 & 0.268 & -0.066 \\
\hline & Deposit growth $(-1)$ & 0.1098 & 0.407 & 0.035 & 0.2873 & 0.053 & 0.065 \\
\hline & Deposit growth (-2) & -0.0421 & 0.695 & -0.015 & 0.1996 & 0.362 & 0.048 \\
\hline & Deposit growth $(-3)$ & -0.1286 & 0.410 & -0.038 & 0.1351 & 0.403 & 0.031 \\
\hline & Share of bills $(-1)$ & 0.0197 & 0.484 & 0.057 & 0.0141 & 0.229 & 0.043 \\
\hline & Cash liquidity $(-1)$ & 0.0213 & 0.637 & 0.039 & -0.0329 & 0.139 & -0.072 \\
\hline & Equity ratio $(-1)$ & 0.0368 & 0.500 & 0.058 & 0.0347 & 0.261 & 0.058 \\
\hline & Branching & -0.0290 & 0.696 & -0.074 & 0.0137 & 0.690 & 0.037 \\
\hline & Foreign share & 0.0140 & 0.766 & 0.024 & -0.0526 & 0.036 & -0.098 \\
\hline & Public & 0.0801 & 0.240 & 0.204 & -0.0638 & 0.212 & -0.172 \\
\hline & Gold cover $(-1)$ & 0.5247 & 0.585 & 0.041 & -0.0785 & 0.345 & -0.038 \\
\hline & Constant & 0.9431 & 0.483 & -- & -0.3200 & 0.058 & -- \\
\hline \multirow[t]{2}{*}{ Select } & $\cdots$ & & & & & & \\
\hline & Rho & 0.039 & 0.823 & & & & \\
\hline \# Obs (total) & 3,689 & & & & & & \\
\hline \# Failures & 19 & & & & & & \\
\hline $\begin{array}{l}\text { Wald test } \\
\text { Chi }^{2}(60):\end{array}$ & 163.35 & & & & & & \\
\hline$p$-value & 0.0000 & & & & & & \\
\hline
\end{tabular}

Table A7: Robustness check for growth in endorsement liabilities - Allowing for structural break after July 1931. 


\section{References}

[1] Arellano, Manuel and Stephen Bond (1991): "Some tests of specification for panel data: Monte Carlo evidence and an application to employment equations," Review of Economic Studies, 58(2), 277-297.

[2] Balderston, Theo (1994): "The banks and the gold standard in the German financial crisis of 1931," Financial History Review, 1, 43-68.

[3] Bank, Die: Diverse issues.

[4] Berlemann, Michael, Kalin Hristov, and Nikolay Nenovsky (2002): "Lending of Last Resort, Moral Hazard and Twin Crises, Lessons from the Bulgarian Financial Crisis 1996/1997," William Davidson Working Paper \#464, May 2002.

[5] Born, Karl Erich (1967): Die deutsche Bankenkrise 1931. München: Piper.

[6] Boyd, John H. and Mark Gertler (1994): "The Role of Large Banks in the Recent U.S. Banking Crisis," Federal Reserve Bank of Minneapolis Quarterly Review, 18(1), 2-21.

[7] Bundesarchiv Berlin (Reichsbank R2501): Files 6462, 6484, 6479, 6482, 6484, 6491-92, 6494-96, 6501, 6557-59, 6572, 6574, 6631, 6634, 6709, 6746, 6925, 6984, 7712, BerlinLichterfelde.

[8] Burdisso, Tamara and Laura D'Amato (2002): "The Argentine Banking and Exchange Crisis of 2001: Can we learn something new about Financial Crises?," Working Paper, Banco Central de la República Argentina.

[9] Carlson, Mark (2004): "Are Branch Banks Better Survivors? Evidence From the Depression Era," Economic Inquiry, 42, 111-126.

[10] Carlson, Mark and Kris James Mitchener (2003): "Branch Banking, Bank Competition, and Financial Stability," Working Paper.

[11] Corsetti, Giancarlo, Paolo Pesenti and Nouriel Roubini (1999): "Paper Tigers? A Model of the Asian Crisis," European Economic Review, 43(7), 1211-1236.

[12] Demsetz, Rebecca S. and Philip E. Strahan (1997): "Diversification, Size, and Risk at Bank Holding Companies," Journal of Money, Credit, and Banking, 29(3), 300-313.

[13] Deutscher Reichs- und Preußischer Staatsanzeiger: Diverse issues.

[14] Enquête-Ausschuß (1930): Der Bankkredit. Verhandlungen und Berichte des Unterausschusses für Geld-, Kredit- und Finanzwesen. Berlin: Mittler \& Sohn.

[15] Ferguson, Thomas and Peter Temin (2003): "Made in Germany: the German Currency Crisis of July 1931," Research in Economic History, 21, 1-53.

[16] Ferguson, Thomas and Peter Temin (2004): "Comment on 'The German Twin Crisis of 1931," Journal of Economic History, 64(3), 872-876.

[17] Friedman, Milton and Anna Schwartz (1963): A Monetary History of the United States, 1867-1970. Princeton: Princeton University Press.

[18] Hardach, Gerd (1976): Weltmarktorientierung und relative Stagnation: Währungspolitik in Deutschland 1924-1931. Berlin: Duncker Humblot. 
[19] Heckman, James. J. (1979): "Sample Selection Bias as a Specification Error," Econometrica, 47, 153-161.

[20] Institut für Konjunkturforschung (1936): Konjunkturstatistisches Handbuch 1936. Hamburg: Hanseatische Verlags-Anstalt.

[21] James, Harold (1984): "The Causes of the German Banking Crisis of 1931," Economic History Review, 38, 68-87.

[22] James, Harold (1985): The Reichsbank and Public Finance in Germany 1924-1933: A Study of the Politics of Economics during the Great Depression. Frankfurt am Main: Fritz Knapp Verlag.

[23] Kaminsky, Graciella L. and Carmen M. Reinhart (1999): "The Twin Crises: The Causes of Banking and Balance-of-Payment Problems," American Economic Review, 89(3), 473-500.

[24] Krugman, Paul (1998): "What happened to Asia?," mimeo, MIT.

[25] Kryzanowski, Lawrence and Gordon S. Roberts (1993): "Canadian Banking Solvency, 1922-1940," Journal of Money, Credit and Banking, 25(3), 361-376.

[26] Petri, Martin H. (1998): The Causes of the German Banking Crisis of July 1931 Viewed from Bank Balance Sheets and the Contemporary Financial Press, Ph.D. dissertation, University of California, Berkeley.

[27] Saling's Börsenpapiere (1930): Deutsche Banken und Bankiers 1929/30, 4. Teil. Berlin, Leipzig, Hamburg: Verlag für Börsen- und Finanzliteratur.

[28] Schnabel, Isabel (2004a): "The German Twin Crisis of 1931," Journal of Economic History, 64(3), 822-871.

[29] Schnabel, Isabel (2004b): "Reply to Thomas Ferguson and Peter Temin's Comment on 'The German Twin Crisis of 1931,"' Journal of Economic History, 64(3), 877-878.

[30] Schumacher, Liliana (2000): "Bank runs and currency run in a system without a safety net: Argentina and the 'tequila' shock," Journal of Monetary Economics, 46, 257-277.

[31] Wicker, Elmus (1996): The banking panics of the Great Depression. Cambridge: Cambridge University Press.

[32] Wooldridge, Jeffrey M. (2002): Econometric Analysis of Cross Section and Panel Data. Cambridge, MA: MIT Press. 